\title{
WOMEN'S INVOLVEMENT IN LIVESTOCK CARE AND MANAGEMENT: IMPLICATIONS FOR THEIR SOCIAL LIFE IN THE PUNJAB, PAKISTAN
}

\author{
Adeela Manzoor ${ }^{1, *}$, Izhar Ahmad Khan', Hira Ashfaq ${ }^{2}$, Norina Jabeen ${ }^{1}$ and \\ Ashfaq Ahmad Maan ${ }^{1}$ \\ ${ }^{1}$ Department of Rural Sociology, Faculty of social sciences, University of Agriculture, Faisalabad, Pakistan; \\ ${ }^{2}$ Community College, University of Agriculture, Faisalabad, Pakistan. \\ *Corresponding author's e-mail: adeela.bhattiuaf@gmail.com
}

\begin{abstract}
Livestock is a natural resource of good quality food, milk, meat, yogurt, butter, etc. Rural women actively participate in livestock management activities but their role is undervalued even though their social life is negatively affected. This paper is an attempt to analyze women's involvement in livestock care and management and its implications for their social life. Multistage sampling technique was used for data collection. Two districts, two tehsils, two union councils and four villages were selected randomly. Six hundred respondents were selected by systematic random sampling technique through Fitzgibbon table. Data were collected with the help of a well-designed interview schedule and analyzed by using different statistical techniques. The results showed that a significant majority of women were involved in making dung-pads and cleaning sheds. Half of the women reported that their livestock work creates problems to meet relatives, attend family functions and for involvement in social activities. It is therefore recommended that families should provide opportunities to women to participate in social activities by sharing their livestock-related responsibilities.
\end{abstract}

Keywords: Livestock management, women's involvement, social life, undervalued.

\section{INTRODUCTION}

All over the world the rural women participate in livestock management and are also involved in agricultural tasks. Women manage and care their animals in good way as compared with men. Women work more hardly in rural activities i.e. domestic, livestock and farming activities. Women have more importance as compared to men in livestock care and management. In the world, two-third of rural people and minority of sub-urban poor people depends on livestock for their livelihood. Approximately 35 million people are involved in livestock related activities (Holmaan et al., 2005). In Punjab, women spend most of the time in different activities such as processing of milk, making and collecting dung cake, cleaning of animals sheds, watering, bathing, making dung-pads and cleaning sheds and grazing animals (Nazli and Hamid, 2007). They also perform difficult tasks like fodder chopping, fodder cutting, rearing, marketing, milking and treatment of animals. Therefore, rural women are involved in almost all livestock-related activities. But, their involvement in livestock-sector is considered as part of their housework and their role in livestock-sector is always undervalued. In the Punjab province of Pakistan, a large number of women participate in livestock care and crop production (FAO, 2015; Arshad et al., 2013; IFAD, 2013; Afzal and Naqvi, 2004; Shivik, 2004; Govt. of Pak., 2002; UN Pak., 2014; Mumtaz, 2005; Taylor, 1985).
Livestock, considered as 'Black Gold of Pakistan' is also considered as sub-sector of agricultural economy in Pakistan. In livestock care and management, gender roles between men and women are different (marketing system, transport, accommodation, sexual harassment and abuse). The experience of women and men are different: vulnerability and risks, value chains, policy, climate change, shocks, anima diseases, political ups and downs, family shocks, information accessibility, introduced new technology, income generation activities, introduce new programs: different trainings programs are introduced, specially community management, livestock management, production and care programs (IFAD, 2013; Nori, 2004; Afzal, 1998; Das, 1995; Campbell and Roe, 1998).

The discussion reflects a great participation of women and their extensive role to manage livestock-related activities are always undervalued. Due to our social values and cultural system. Therefore, this study is designed with the objectives to study the extent of women's involvement in livestock care and management, assess the implications of livestock related work for women's social life and assess some policy measure for women's empowerment in Punjabi society.

\section{MATERIALS AND METHODS}

A sample survey was carried out according to the plan of the research. The study was conducted in the rural areas of Punjab, province of Pakistan. Multi-stage sampling technique 
was used for selecting the universe and the sample. At the first stage, two districts were selected by using simple random sampling technique. At the second stage, one tehsil from each selected district was selected through simple random sampling technique. At the third stage, one union council from each tehsil was selected. At the fourth stage, two villages from each union council were selected randomly. Simple random sampling technique was used for selecting a street from the selected village. Systematic random sampling technique was used for selecting the house households from each selected street. Every third house in every street was selected and the female head of the household was selected for interview. Proportionate sampling technique was used for selecting sample for interview from each village. A total sample 600 female respondents was selected by systematic random sampling technique through Fitzgibbon table. The data were collected with the help of interview schedule. An interview schedule was developed in the light of objectives of the study. The interview schedule was consisted upon, both, close-ended and open-ended questions were analyzed by using different statistical techniques and the results and discussion are presented below.

\section{RESULTS AND DISCUSSION}

The data presented in figure 1 depict that in majority $(53.8 \%)$ cases, the task of milking was performed by the women themselves. In the province of Punjab, the figures presented by Narmatha et al. (2009) and Rehman and Gulgoona (2000) are too high $(91.6,89.2$ and 94.0\%) to believe for women's engagement in milking animals. These three figures seems logical and believable as compared to the very high figures presented before. However, a provincial level study is needed to gauge a more valid and reliable picture of the issue under discussion. The small sample size, sampling procedures and other differentials in methodologies of these studies can be taken as explanations for the above mentioned trends of the reported data on milking animals. A vast majority (72.5\%) of the respondents reported that feeding and watering of the animals were done by the women. The findings of the study conducted by Arshad et al. (2013) supports the findings of the present study as they have reported that $75.8 \%$ of the women were involved in feeding and watering animals. More than half $(52 \%)$ of the respondents told that women have been making arrangements for sick animals' treatment. Another study carried out by Arshad et al. (2010) also found that Pakistani women have been playing a significant role in livestock management practices, including looking after the health of herd. More than three-fourth (78.5\%) of the respondents reported that fodder cutting was done by them. The findings are supported by the studies conducted by Arshad et al. (2010, 2013). The findings of these studies showed that 71.2 and $63.3 \%$ of the women told, respectively, that fodder cutting was done by them. A great majority
$(88.3 \%)$ of the respondents were cleaning animals' sheds, themselves. Narmatha et al. (2009) also found that more than $95 \%$ of the women themselves were cleaning animals' sheds. A majority $(67.8 \%)$ of the respondents reported that the task of grazing animals was performed by women. An overwhelming majority $(94.5 \%)$ of the respondents told that dung-pads were made by women. Less than a half (42.7\%) of the women said that rearing was done by themselves. A majority $(59.5 \%)$ of the respondents told that bathing was performed by women. Rehman and Gulgoona (2000) and Arshad et al. (2013) have reported that 90.7 and $26.7 \%$ of the women were engaged in bathing animals.

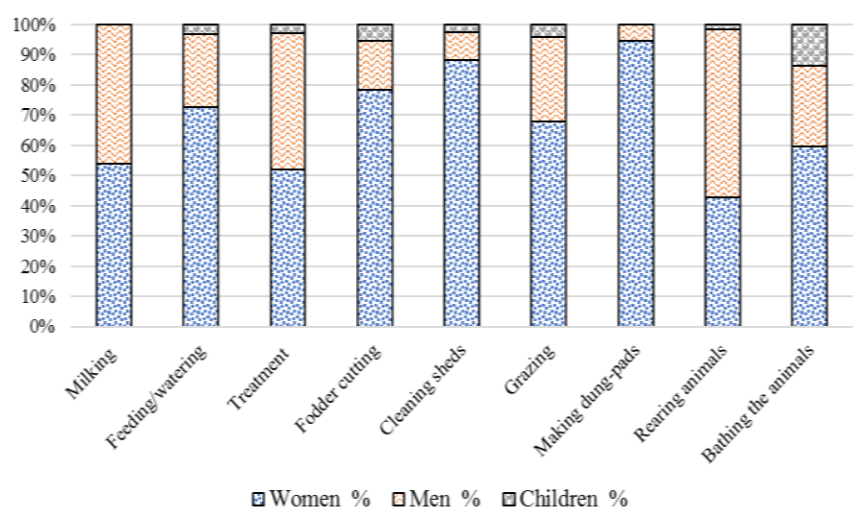

Figure 1. Women's involvement in Livestock care and management activities.

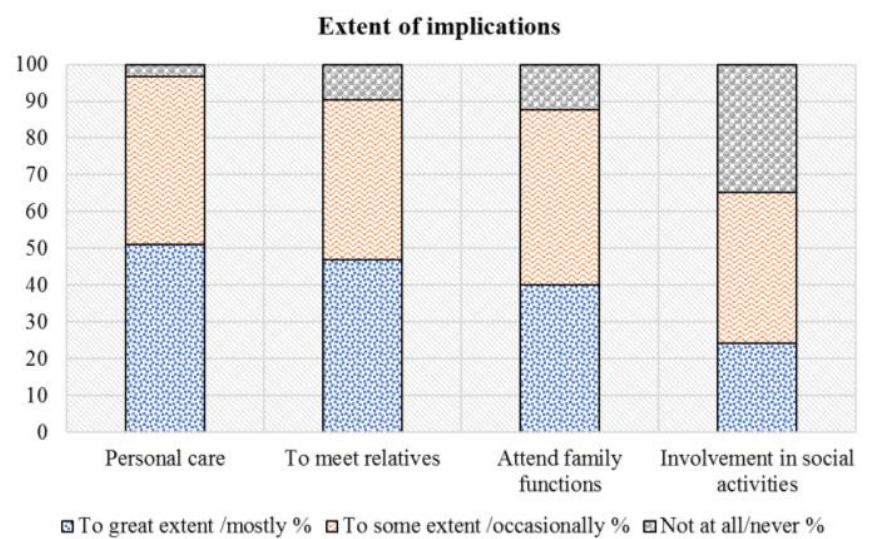

Figure 2. Distribution of respondents as livestock management creates problems in personal care, to meet relatives and participation in social activities.

The data presented in Figure 2 show that a little more than a half $(51.0 \%)$ of the women told that their livestock management creates problems for their personal care to a great extent. Less than a half $(45.8 \%)$ of them told that livestock management creates problem for their personal care to some extent. In summary, $3.2 \%$ of the respondents separated that. Less than a half $(46.8 \%$ and $43.5 \%)$ of the 
respondents told that livestock management creates problems to a great extent and to some extent, respectively, in meeting relatives. Less than a half $(47.5 \%)$ of the respondents told that livestock management creates problems to some extent to attend family functions. However, a little more than two-fifth $(40.2 \%)$ of the respondents said that they were facing problems to great extent in attending family functions due to livestock management activities. More than one-fifth (41.2\%) of the respondents were 'to some extent' participating in social activities. Moreover, more than one-third (34.7\%) of the women never participated in social activities. It said that livestock care and management activities were affecting women's social life.

Table 1 presents the association between women's problems in personal care and level of their involvement in livestock care and management activities. Chi-square value shows a highly significant association between women's problems in personal care and level of their involvement in livestock care and management. Gamma value shows a positive relationship between the variables. It means that women who have had high level of involvement in livestock care and management activities, they faced great extent problems in personal care. Therefore, the hypothesis "There is an association between women's problems in personal care and level of their involvement in livestock care and management" is accepted. Data supports that (Sharif, 2012) a huge majority (89.1\%) of the respondents, said that livestock care and management activities created problems for them in meeting their relatives. Anwar (2012) has also found that a very huge majority $(95.0 \%)$ of the women reported that their health was suffering due to their involvement in livestock care and management. This is a matter of great concern for the policy-makers that on the one hand, concern has been shown about livestock health, but, the health of women engaged in livestock care and management is neglected, on the other hand.

Table 1. Association between women's problems in personal care and level of their involvement in livestock care and management.

\begin{tabular}{|c|c|c|c|c|}
\hline \multirow{2}{*}{$\begin{array}{l}\text { Women's } \\
\text { involvement in } \\
\text { livestock care \& } \\
\text { management }\end{array}$} & \multicolumn{3}{|c|}{$\begin{array}{c}\text { Extent of problems in } \\
\text { personal care }\end{array}$} & \multirow[t]{2}{*}{ Total } \\
\hline & $\begin{array}{c}\text { Not at } \\
\text { all }\end{array}$ & $\begin{array}{c}\text { To some } \\
\text { extent }\end{array}$ & $\begin{array}{c}\text { To a great } \\
\text { extent }\end{array}$ & \\
\hline \multirow[t]{2}{*}{ Low } & 9 & 36 & 9 & 54 \\
\hline & $47.4 \%$ & $13.1 \%$ & $2.9 \%$ & $9.0 \%$ \\
\hline \multirow[t]{2}{*}{ Medium } & 5 & 95 & 59 & 159 \\
\hline & $26.3 \%$ & $34.5 \%$ & $19.3 \%$ & $26.5 \%$ \\
\hline \multirow[t]{2}{*}{ High } & 5 & 144 & 238 & 387 \\
\hline & $26.3 \%$ & $52.4 \%$ & $77.8 \%$ & $64.5 .0 \%$ \\
\hline \multirow[t]{2}{*}{ Total } & 19 & 275 & 306 & 600 \\
\hline & $100 \%$ & $100 \%$ & $100 \%$ & $100.0 \%$ \\
\hline
\end{tabular}

Table 2 presents the association between extent of women's problems in attending family functions and level of their involvement in livestock care and management. Chi-square value shows a highly significant association between extent of women's problems in attending family functions and level of their involvement in livestock care and management. Gamma value shows a positive relationship between the variables. It means that the women who had high level of involvement in livestock care and management, they faced great extent problems in attending family functions. Therefore, the hypothesis "There is an association between extent of women's problems in attending family functions and level of their involvement in livestock care and management" is accepted. Literature further narrates that women spend most of their time in different activities like processing of milk, making and collecting dung cakes, cleaning animals' sheds, watering, bathing and grazing animals. Women also perform difficult tasks including fodder chopping, fodder cutting, rearing, marketing, milking, collecting and making dung pads and treatment of animals (Riasat et al., 2014; Govt. of Pak., 2015; Munawar et al., 2013; IFAD, 2013; Nadeem et al., 2012; Govt. of Pak., 2002; Nazli and Hamid, 2007; Iftikhar et al., 2007).

Table 2. Association between extent of problems in attending family functions and level of involvement in livestock care and management.

\begin{tabular}{lcccc}
\hline Women's & \multicolumn{3}{c}{$\begin{array}{c}\text { Extent of Problems in } \\
\text { involvement in } \\
\text { livestock care }\end{array}$} & \multicolumn{2}{c}{ Tottending family functions } & \\
\cline { 2 - 4 } \& management & $\begin{array}{c}\text { Not at } \\
\text { all }\end{array}$ & $\begin{array}{c}\text { To some } \\
\text { extent }\end{array}$ & $\begin{array}{c}\text { To great } \\
\text { extent }\end{array}$ \\
\hline Low & 9 & 22 & 23 & 54 \\
& $12.2 \%$ & $7.7 \%$ & $9.5 \%$ & $9.0 \%$ \\
Medium & 19 & 102 & 38 & 159 \\
& $25.7 \%$ & $35.8 \%$ & $15.8 \%$ & $26.5 \%$ \\
High & 46 & 161 & 180 & 387 \\
& $62.2 \%$ & $56.5 \%$ & $74.7 \%$ & $64.5 \%$ \\
Total & 74 & 285 & 241 & 600 \\
& $100 \%$ & $100 \%$ & $100 \%$ & $100.0 \%$ \\
\hline
\end{tabular}

Chi-square $=27.97 ;$ d.f. $=4$; Significance $=.000 * * ;$ Gamma $=0.224 ; * *=$ Highly-Significant

Conclusion: Women of the Punjab province actively participated in livestock-related activities i.e. milking, feeding and watering, treatment, fodder cutting, cleaning sheds, grazing, making dung-pads, rearing and bathing the animals. Due to cultural milieu of the Punjabi rural society, women were involved in doing this difficult job but their social life is being affected. Women involvement in social activities was very low and their work created problems in personal care, meeting with relatives and attending family functions. It is recommended that families should share women's livestockrelated activities and facilitate them to attend social functions and participate in social activities. 


\section{REFERENCES}

Afzal, M. and A.N. Naqvi. 2004. Livestock Resources of Pakistan: Present status and future trends. Pak. J. Agric. Res. 9:1-2.

Afzal, M. 1998. Pakistan Country Paper. In: E.F. Thomson, R. von Kaufmann, H.L. Pun, T. Treacher and H. von Houton (eds.), Global Agenda for Livestock Research. International Centre for Agricultural Research in Dry Area, Aleppo, Syria; pp.120-126.

Anonymous. 2014-15. Pakistan Economic Survey 2014-15. Finance and Economic Affairs Division, Ministry of Finance, Govt. of Pakistan, Islamabad, Pakistan.

Anwar, R. 2012. Participation of female members of the rural family in livestock care and management in district Faisalabad. M.Sc. Diss., Dept. Rural Sociology, Uni. of Agriculture, Faisalabad, Pakistan.

Arshad, S., S. Muhammad and I. Ashraf. 2013. Women's participation in livestock farming activities. J. Anim. Plant Sci. 23:304-308.

Arshad, S., S. Muhammad, M.A. Randhawa, I. Ashraf and K.M. Choudhry. 2010. Rural women's involvement in decision-making regarding livestock management. J. Anim. Plant Sci. 47:1-4.

Cambell, D and A. Roe. 1998. Results of a preliminary survey of livestock owner. In: R.W. Dutton, J.I. Clarke and A. Battikhi (eds.), Arid Land Resources and their Management. Routledge, UK and USA; pp.189-196.

Das, M.D. 1995. Agriculture survey 1995. Crop and Livestock Production: Part-1 World Review. Food and Agriculture Organization of the United Nations, Rome; pp.3-5.

GoP. 2002-03. Economic Survey of Pakistan 2002-03. Economic Advisory Wing, Finance Division, Govt. of Pakistan, Islamabad, Pakistan.

Holmaan, F., L. Rivas, N. Urbina, B. Rivera, L.A. Giraldo, S. Guzman, M. Martinez, A. Medina and G. Ramirez. 2005. The role of livestock in poverty alleviation: An analysis of Colombia. Livestock Res. Rural Devel. 17:1-15.

IFAD. 2013. Livestock and Access to Markets. International Fund for Agricultural Development.

Iftikhar, N., T. Ali and M. Ahmad. 2007. Role of rural women in agriculture and their training needs. J. Anim. Plant Sci. 17:93-95.
Mumtaz, K. 2005. Women's representation, effectiveness and leadership in south Asia. Fifth South Asia Regional Ministerial Conference, May. 3-5, 2005. Celebrating Beijing plus ten Islamabad, Pakistan; pp.14-19.

Munawar, M., U. Safdar, M. Luqman, T.M. Butt, M.Z.Y. Hassan and M.F. Khalid. 2013. Factors inhibiting the participation of rural women in livestock production activities. J. Agric. Res. 51:213-220.

Nadeem, N., M.I. Javed, I. Hassan, W. Khurshid and A. Ali. 2012. Total factor productivity growth and performance of livestock sector in Punjab, Pakistan. J. Agric. Res. 50:279-287.

Narmatha, N., V. Uma, A. Lal and R. Geetha. 2009. Level of participation of women in livestock farming activities. J. Vet. Anim. Sci. 5:4-8.

Nazli, H. and S. Hamid. 2007. Role of gender and intra household dynamics in Pakistan. Islamabad, Pakistan Institute of Development Economics (PIDE), Govt. of Pakistan; pp: 1-35.

Nori, M. 2004. Gender, Pastoralism and Islam: A Challenging Crucible. International Fund for Agricultural Development. Report for the Milking Drylands, Marie Curie. pp. 1-15.

Rehman, S and Y. Gulgoona. 2000. Participation and practices in livestock care and management by rural female members in salt affected area. Int. J. Agric. Biol. 2:386-387.

Riasat, A., M. I. Zafar, I.A. Khan, R.M. Amir and G. Riasat. 2014. Rural development through women participation in livestock care and management in district Faisalabad. J. Glob. Innov. Agric. 2:31-34.

Shaheed, F. and K. Mumtaz. 1990. Women's Economic Participation in Pakistan: a Status Report. Shirkatgah and Lahore, Pakistan.

Sharif, T. 2012. The impact of female involvement in livestock and agricultural activities in district Faisalabad. M.Sc. Diss., Inst. Agric. Ext. and Rural Dev., Univ. Agric., Faisalabad, Pakistan.

Shivik, J.A. 2004. Non-lethal alternatives for predation management. Sheep Goat Res. J. 19:64-71.

Taylor, D. 1985. Agriculture: Women in Agricultural Systems. Women a World Report. A course reader for IMA management course for rural women in rural development, IMA publishers Robertson, UK; pp.1-7.

United Nations Pakistan. 2014. One UN Report. Islamabad, Pakistan; pp.48-49. 